\title{
The molecular genetics related to polydactyly: an updated review
}

\author{
Pan Xie ${ }^{1,2}$, Fu-Qiang Yuan ${ }^{1,2}$, Hong-Hao Zhou ${ }^{1,2}, \mathrm{Xi}^{\mathrm{Li}^{1,2}}{ }^{\text {Zhao-Qian Liu }}{ }^{1,2}$ \\ ${ }^{1}$ Department of Clinical Pharmacology and National Clinical Research Center for Geriatric Disorders, Xiangya Hospital, Central South University, \\ Changsha, China; ${ }^{2}$ Institute of Clinical Pharmacology, Central South University, Hunan Key Laboratory of Pharmacogenetics, Changsha, China \\ Contributions: (I) Conception and design: P Xie, X Li; (II) Administrative support: HH Zhou, ZQ Liu; (III) Provision of study materials or patients: \\ P Xie; (IV) Collection and assembly of data: P Xie; (V) Data analysis and interpretation: P Xie, FQ Yuan; (VI) Manuscript writing: All authors; (VII) \\ Final approval of manuscript: All authors. \\ Correspondence to: Prof. Zhao-Qian Liu; Prof. Xi Li. Department of Clinical Pharmacology, Xiangya Hospital, Central South University, Changsha, \\ China; Institute of Clinical Pharmacology, Central South University, Hunan Key Laboratory of Pharmacogenetics, Changsha, China. \\ Email: zqliu@csu.edu.cn; lixi6931430@126.com.
}

\begin{abstract}
Polydactyly is the most common hereditary limb malformation in clinical practice. It can appear as an isolated disease or as part of a complex syndrome. This paper summarizes and updates the classification and phenotype of independent polydactyly, the cellular molecular basis of their development, the key signaling pathways that regulate polydactyly and related genes (SHH-GLI3 pathway and the Hox family). We believe that this information has very important clinical value. On the other hand, it can also help researchers understand the molecular basis of forming polydactyly more deeply, and will contribute to more systematic genetic studies in the future.
\end{abstract}

Keywords: Polydactyly; preaxial polydactyly (PPD); postaxial polydactyly (PAP); genetics

Received: 22 May 2020; Accepted: 06 August 2020.

doi: $10.21037 /$ prpm-20-2

View this article at: http://dx.doi.org/10.21037/prpm-20-2

\section{Introduction}

Polydactyly is the most common hereditary limb malformation, and its total incidence is about $0.3-3.6 \%$ of the surviving infants (1). The disease is autosomal dominant and clinically manifested as extra fingers or toes. Polydactyly has similar phenotypes in different species including humans, mice, and chickens, and its clinical typing principles are basically the same $(2,3)$. Polydactyly is more common in the thumb and little finger, and the extra phalangeal shape and structure can be either a small fleshy growth or a nearly normal developing finger with nails, bones, joints, tendons, and neurovascular bundles (4). The only current treatment for the disease is surgical removal of excess fingers or toes, which will not regenerate after surgery, and there is no other treatment (5).

The exact etiology of polydactyly is not clear at present, most are sporadic, on the one hand, the disease is related to environmental factors. For example, during the early 4-8 weeks of pregnancy, embryonic limb bud differentiation is affected by viral infection, drugs, radiation and other environmental factors, which may lead to finger differentiation disorders and limb deformity (6-10). On the other hand, many clinical samples have proved that some patients have a family disease, and the pathogenic genes of multi-toed babies may be inherited from their parents $(11,12)$. In recent years, with the further development of sequencing technology, some studies have found that de novo mutations of important genes related to polydactyly can also lead to polydactyly in the next generation (13-17). For the former, we call for better health care and nutrition during pregnancy to avoid bacterial and viral infections and possible teratogenic factors such as radiation and drugs. For the latter, it is important to understand the genetic and molecular characteristics of polydactyly and to identify and confirm the genes and loci that cause the disease, which can provide an important reference for the subsequent genetic and molecular biology studies of the disease. This paper reviews and updates the above information. 


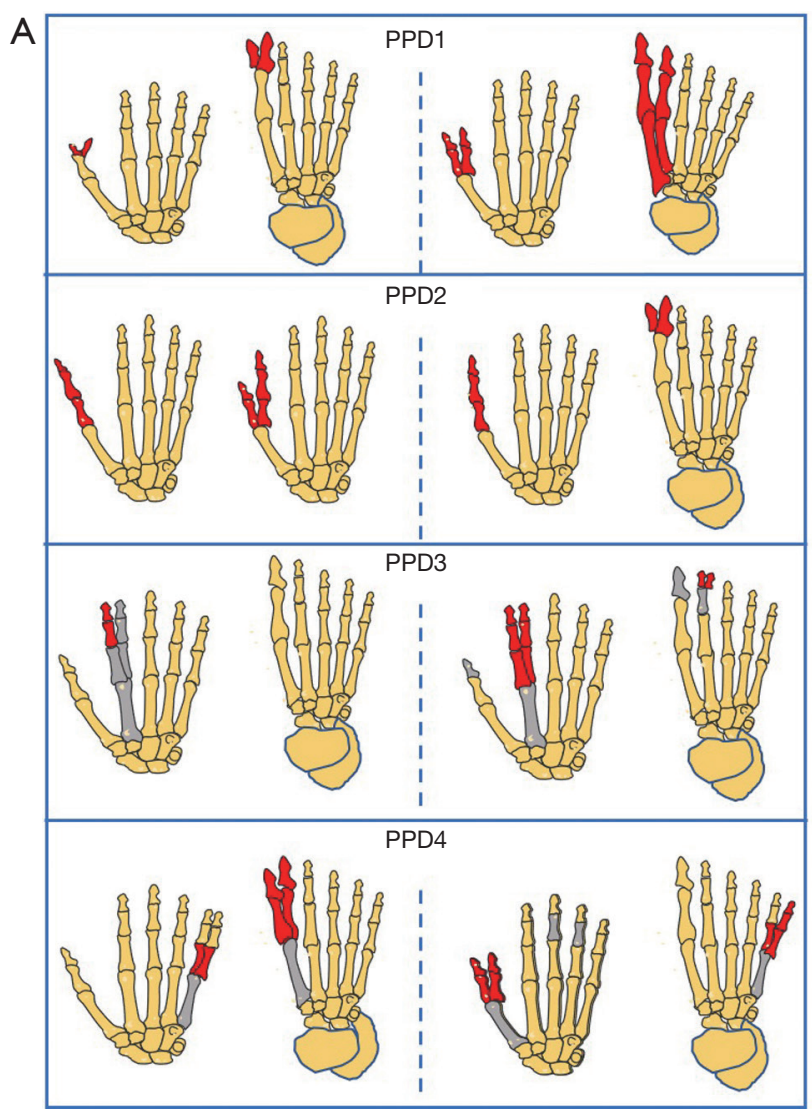

B

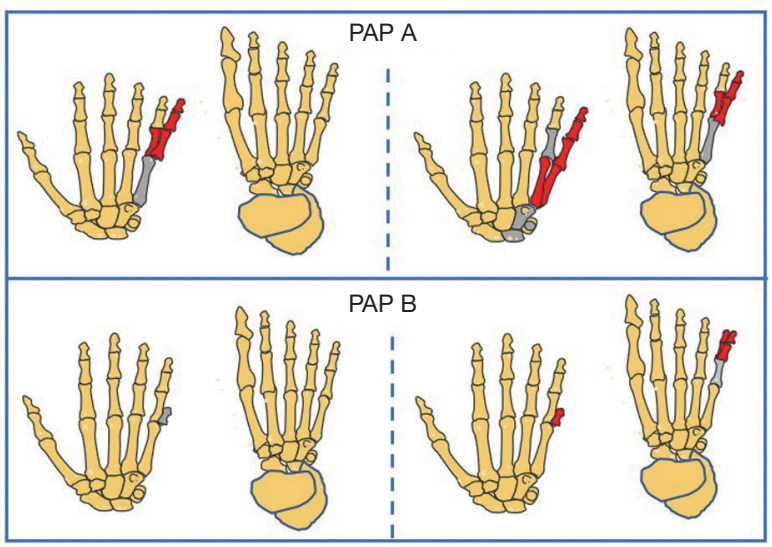

Figure 1 Cartoon diagrams of autopods showing PPD and PAP. (A) Four types of PPD; (B) two types of PAP. Yellow represents normal fingers (toes); red is for extra fingers (toes); the grey is for stunted fingers (toes). PPD, preaxial polydactyly; PAP, postaxial polydactyly.

\section{Clinical classification of polydactyly}

Polydactyly can occur as an isolated disease (non-syndromic polydactyly) or as part of an abnormal syndrome (syndromic polydactyly). From an anatomical perspective, the two most common types of polydactyly are the preaxial polydactyly (PPD) and the postaxial polydactyly (PAP) (Figure 1). Of course, there are more rare types, such as mesoaxial or central polydactyly, mirror image polydactyly (MIP), palmer and dorsal polydactyly, etc. $(18,19)$. PPD is defined as a supernumerary digit affecting the first digits, this type of polydactyly is rare, accounting for about $8 \%$ to $15 \%$ of polydactyly. This type is mostly found in southeast Asia, such as Malaysia and the Philippines, etc. PPD is further subdivided into four subclasses according to the location and morphology of redundant fingers (toes). PAP involves the fifth digits and is the most common type of polydactyly, accounting for approximately $77 \%$ to $87 \%$ of the total polydactyly. The incidence of this type of polydactyly varies along ethnic lines and is particularly common in African.
PAP can be further classified into types $\mathrm{A}$ and $\mathrm{B}$, according to the extra digit(s) being either well developed (type A, PAPA) or rudimentary (type B, PAPB). And PAPA can be divided into six genetic types (20). In this paper, according to the specific classification of polydactyly, we summarized and updated the information of disease phenotype, chromosome location, genetic mode and related pathogenic genes (Table 1).

\section{Cellular molecular basis of limb development}

\section{Morphogenesis of fingers (toes)}

Fingers (toes) is a special product of the evolution of tetrapods. During embryonic development, they condense as a single cartilage, which then divides and grows. Human limb buds begin to form at the fourth weekend of embryonic development, after which the interaction between genes and various signaling factors guarantees the normal shape, function and number of fingers (toes) $(53,54)$. During 


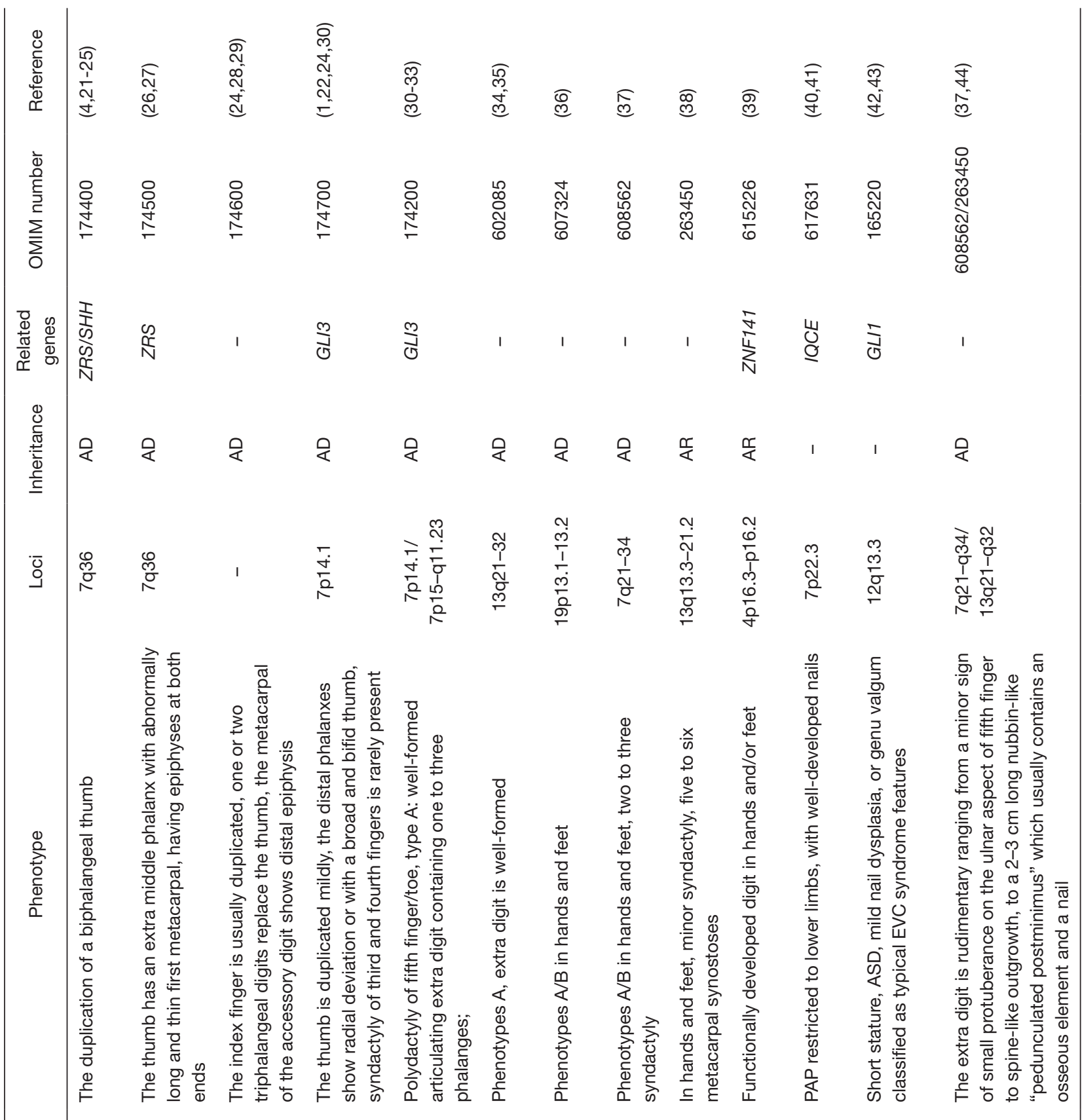

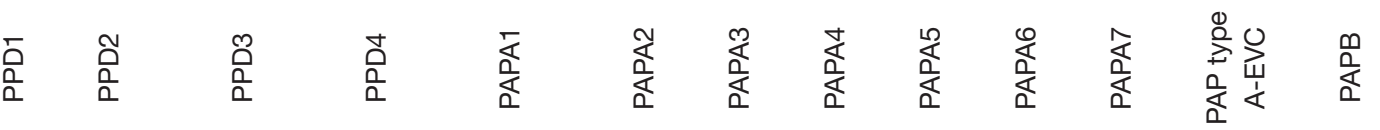




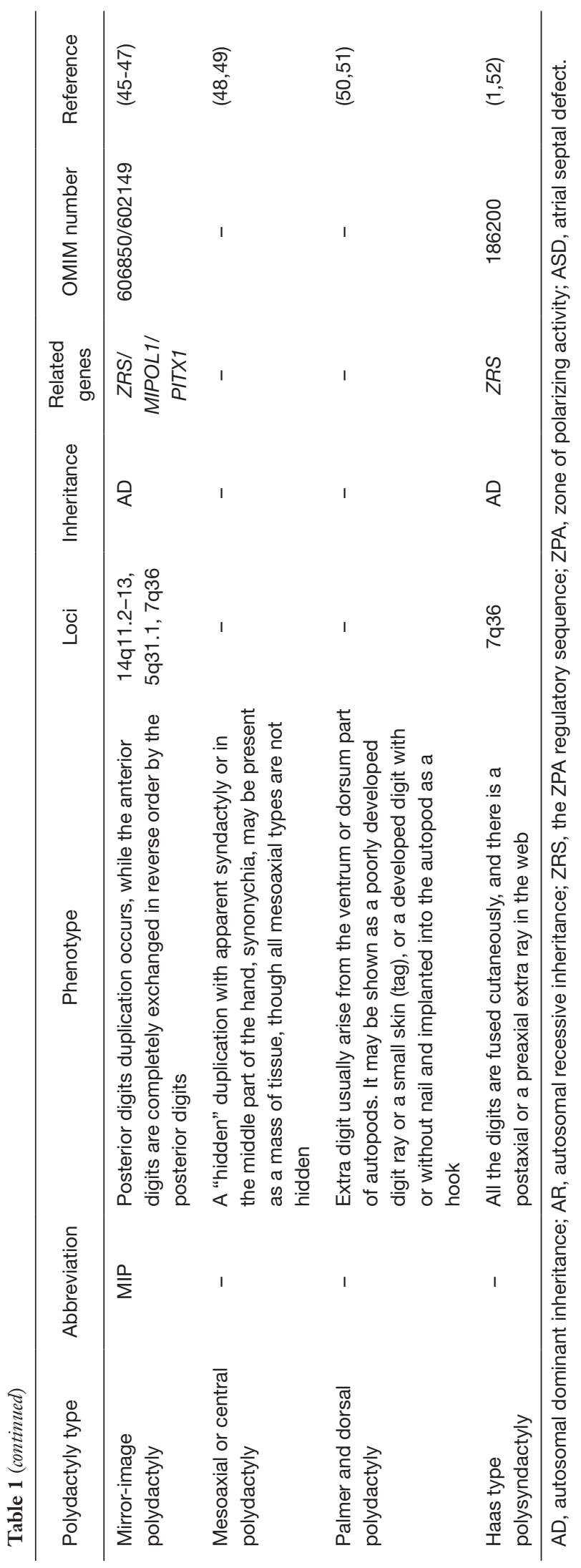

limb development, biological signals generated at specific locations play a crucial role in the fate of cells in later embryonic development, and errors in these signaling pathways can lead to congenital limb malformations (55). The appendage of vertebrates is formed by the mesoderm of the body wall and the outer epidermis. The bones in these limbs consist of three main parts: the ones near the side of the body wall called stylopod (e.g., humerus, femur), the middle part zeugopod (e.g., ulna, radius), and the most distant one autopod (e.g., metacarpal, digits) (56) (Figure 2A). Building a complete appendage requires accurate location information, that is, functioning in a three-dimensional (or four-dimensional including time) coordinated system. A series of proteins have been identified that play a role in the formation of the anterior-posterior axis (A-P axis), the proximal-distal axis (P-D axis) and the dorsal-ventral axis (D-V axis) of appendages (57) (Figure 2B).

The first sign of early appendage development is the proliferation of mesodermal cells along the long axis of the embryo, gradually forming thick clumps of cells under the epidermis, which are separated from the lateral lamellar mesoderm and ganglionic mesoderm of the appendage field, and then transformed into mesenchymal cells for migration. Thereafter, limb development begins with the proliferation of mesenchymal cells separated from the limb skeletal precursors and from the limb muscle precursors. These cells converge under the endodermal tissue to form a circular protuberant called a limb bud. Therefore, the signal of limb bud formation comes from the lateral plate mesoderm cells, which secrete the fibroblast growth factor 10 (FGF10), and FGF10 can promote the interaction of limb formation between the ectoderm and mesoderm. Studies have shown that FGF10 is highly expressed in the lateral plate mesoderm where the limb is normally formed. When the researchers artificially transplanted cells that secreted FGF10 into the flanks of the chicken embryo, FGF10 caused an ectophobic limb to form $(58,59)$.

\section{The regulatory effect of the apical ectodermal ridge (AER)}

In birds and mammals, the mesoderm induces the elongation of the ectoderm cells at the anterior and posterior edges of the tip of limb buds to form a thickened special structure called the AER $(60,61)$. This ribbed structure will move with the fingerlike edges of the limb and will become the main signaling center of the developing limb. It plays the following roles: (I) to maintain the mesenchymal cells below it in a plastic, proliferating 

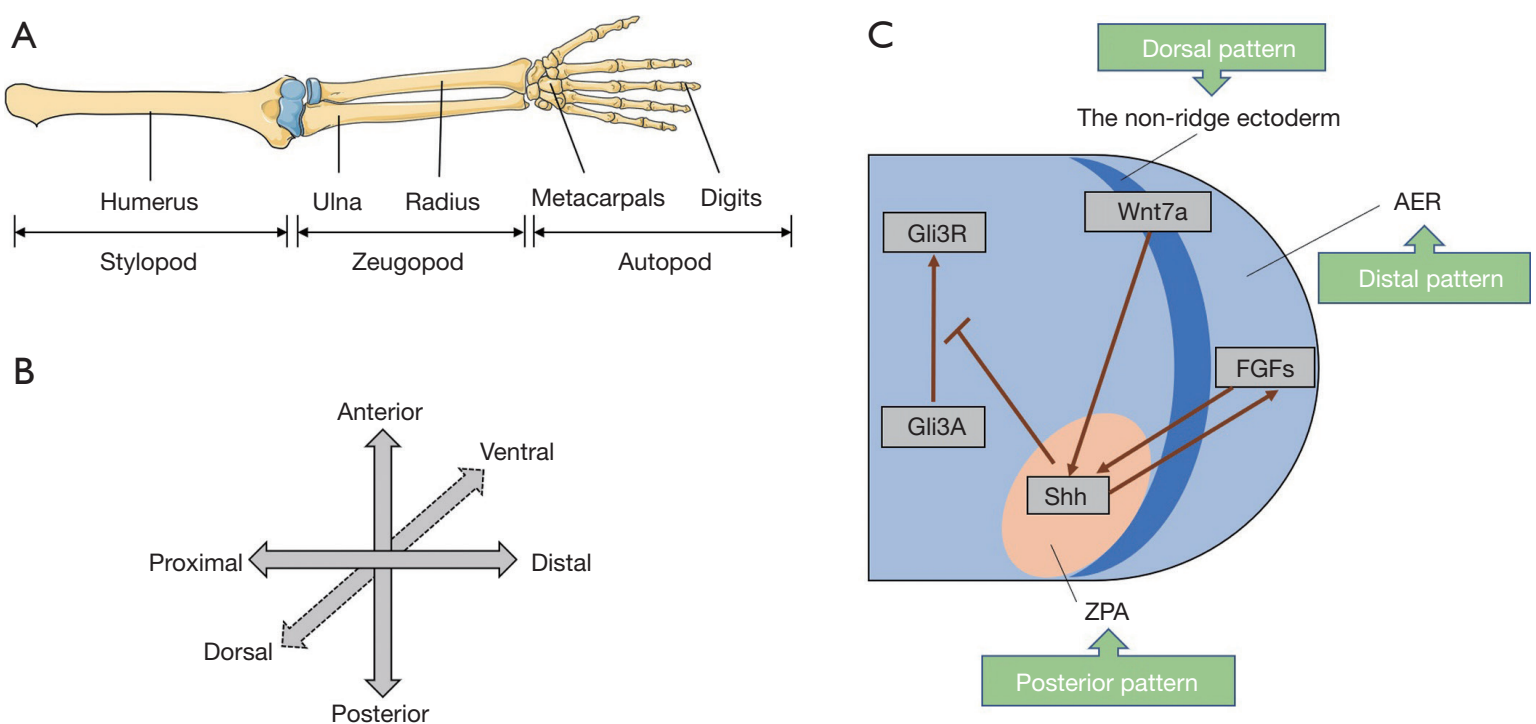

Figure 2 Cellular molecular basis of limb development. (A) The bone composition of these appendages; (B) three axis of limb development; (C) three signal centers and their interactions during limb development.

phase, enabling it to complete the growth of the P-D limb; (II) maintain a certain amount of performance for those molecules that can cause the A-P axis (i.e., thumb to pinky) formation; (III) and leads to protein interaction of the A-P axis and the D-V axis, so that each cell can get how to differentiate instruction. The outward growth of appendages involves a continuous interaction between AER and mesoderm (62). Once the mesoderm induces the formation of AER in the ectoderm above it, the interaction between the AER and the mesoderm is the most important FGFs for the outward growth of appendages, including FGF8, FGF4, FGF2, FGF9, and FGF17, which are all expressed in the AER (63-65). Among them, FGF8 is expressed in the AER of all cells, throughout the beginning and end of limb development, and is considered as a marker of AER. Therefore, FGF8 plays a leading role in the interaction between AER and mesoderm $(66,67)$.

\section{The regulatory effect of the zone of polarizing activity (ZPA)}

The second important signal center in limb development is ZPA in the mesenchymal cells at the back of the limb bud. The signal factor SHH generated by ZPA is the basis for the formation of the A-P axis. Artificial transplantation of posterior limb bud cells to anterior edge cells can cause the production of extra limbs, and it was found that ZPA was produced in this process (68). ZPA cells produce $\mathrm{SHH}$, which is thought to be a signaling molecule that originates from ZPA and regulates all of its function. The resulting replicative limb, or polydactyly, is caused by an early activation of abnormal SHH signals, which can be influenced by the external environment or caused by the body's own signal disorders (69).

\section{The regulatory effect of the non-ridge ectoderm}

The formation of the limb $\mathrm{D}-\mathrm{V}$ axis depends on the ectoderm without AER (70). The D-V axis is associated with cell specialization from both the mesoderm and ectoderm, and its differentiation may be induced by the specific paracrine factor ( $\mathrm{Wnt} 7 \mathrm{a}$ ) in the ectoderm of the dorsal limb bud (71). This region has a special gene expression characteristic. The dorsal mesoderm induced both rFng and Wnt7a expression in dorsal limb buds, while the abdominal mesoderm induced Engrailed-1 (En-1) expression in the limb buds. The mutual inhibition between En-1 expressing cells and rFng expressing cells will determine the central margin of the apical ectodermal crest. En-1 and Wnt7a inhibited each other, so the abdominal area of limb bud was located $(71,72)$.

The three signal centers in limb formation are interdependent and this interaction is necessary for the normal development of the limb. The specific manifestations are as follows: (I) the polarizing active region (Sonic hedgehog) was established by AER (FGF8) and dHAND; (II) FGFs generation is induced by Sonic 
hedgehog (in the polarizing active region) (in the AER) by $\mathrm{SHH}$ inducing Gremlin, which inhibits FGFs BMP inhibition; (III) maintain the expression of Sonic hedgehog by Wnt7a (in the ventral ectoderm); (IV) Sonic hedgehog blocks the division of Gli3 into the form of repressor, and maintains the concentration gradient between Gli3 activator and Gli3 repressor $(73,74)$ (Figure $2 C$ ).

\section{Key signaling pathways and related genes}

So far, some progress has been made in the study of genetic regulation of Polydactyly, and some genes related to Polydactyly have been located, which are mainly concentrated on chromosome 2 and 7 of human. In addition, polydactyly-related genes were also found in 13q21-q32 and 19p13-p13.2 regions of human chromosome. At present, the genes related to limb development have been known to be SHH, LMBR1/2, the Hox family, The Gli family, PTCH1, $S M O, E N-2, B M P$, etc. The genes and signaling pathways that affect polydactyly are basically the same among different species (75).

\section{SHH-Gli3 patbway}

SHH is an important secretory factor in limb development and has been located in the $7 \mathrm{q} 36$ region of human chromosome. SHH can cause limb abnormalities in vertebrates including mice, chickens and humans. Normally, $\mathrm{SHH}$ is only expressed in the back of limb buds of mice, and the loss of function of $\mathrm{SHH}$ leads to severe limb fracture, while the abnormal expression of $S H H$ in the forelimb will lead to finger (toe) duplication. The factors controlling $\mathrm{SHH}$ expression in limb buds can be divided into positive and negative regulators (68). Studies have shown that at least 216 mutations in the $S H H$ gene can lead to abnormal limb development, with polydactyly occurring more frequently (30). Hand2, Tbx3, Pbx1, Pbx2, Hox10, Hox11, Hox 12 and Hox13 may activate $S H H$ expression in the posterior limb bud, and loss-of-function mutants of those genes can cause reduced or absent $S H H$ expression in this region (20). Among these regulators of $S H H, Z R S$ has been reported to be associated with many types of Polydactyly. $Z R S$ is located in the 5 th intron of $L M B R 1$, close to $1 \mathrm{MB}$ from $S H H$, and is highly conserved in excess of $800 \mathrm{bp}$. It is necessary to control the expression of $S H H$ in limb buds, but not in other parts of the developing embryo $(27,68,76)$. Mutations in the $Z R S$ lead to the heterotopic expression of the $S H H$, which has been reported to cause PPD in many species, including mice, dogs, cats, chickens, and humans (77-82).

Gli3 is another crucial gene in this pathway. It is a member of the Gli family of zinc finger transcription factors, located on the human chromosome $7 \mathrm{p} 13$, and is a gene encoding zinc finger proteins (83). Gli3 transcription factor plays an important role in the regulation of $\mathrm{SHH}$ gene expression, and its mutation affects its normal expression, resulting in anteroposterior polydactyly, anteroposterior polydactyly and minor facial deformities. Gli3 exists in two different forms (Gli3R and Gli3A), and the proportion of Gli3R/Gli3A is directly involved in the development of digits (84). According to reports, 225 genes have been identified in the Gli3 gene that can cause limb abnormalities, many of which can lead to polydactyly (30).

$L M B R l$ and $L M B R 2$ are the key genes leading to abnormal limb development in mammals, including human (85). $L M B R l$ encodes a transmembrane receptor that is an important regulator of SHH upstream. The intron 5 (ZRS) of this gene contains cis-acting element of $\mathrm{SHH}$, so its expression changes can lead to PPD (86). Multiple studies have shown that mutations in $Z R S$ in humans and mice lead to different types of preaxial polydactyl phenotypes, such as ZRS $404 \mathrm{G}>\mathrm{A}$, ZRS $404 \mathrm{G}>\mathrm{T}$, ZRS $404 \mathrm{G}>\mathrm{C}$, ZRS 417 $\mathrm{A}>\mathrm{G}$ and ZRS $619 \mathrm{C}>\mathrm{T}(23,87-90)$.

PTCH1 and SMO are also important intermediate genes in this pathway. After SHH-PTCH interaction, due to the loss inhibition of PTCH to SMO, SMO activates Gli3R into the activated Gli3A form. SMO, on the other hand, activates $\mathrm{SHH}$ signals in the presence of SHH. In the absence of SHH, PTCH receptor inhibits SMO function and thus has inhibitory function $(91,92)$. Therefore, we believe that PTCH1, SMO and SHH have regulatory roles in both pairs, maintaining a dynamic balance between them to ensure normal limb development. Finally, $S H H$ expression of the regulatory factors Twist1, Hand2, and Etv also maintains a precise balance during embryonic development, forming an AP pattern in the limb. Twist1 can form homodimers/heterodimers with Hand2, which can be antagonized by overexpressing Etv (69). Additionally, Gli3 protein directly inhibits the transcription of Hand2 (93).

The dynamic balance between Gli3R/Gli3A, Twist1Hand2-Etv and SHH-PTCH-SMO is an important cornerstone to maintain the stability of the SHH-Gli3 pathway. Once this balance is broken, the pathway will show abnormal signals, which will eventually lead to abnormal limb development and malformation during embryonic development. And these three kinds of balance 

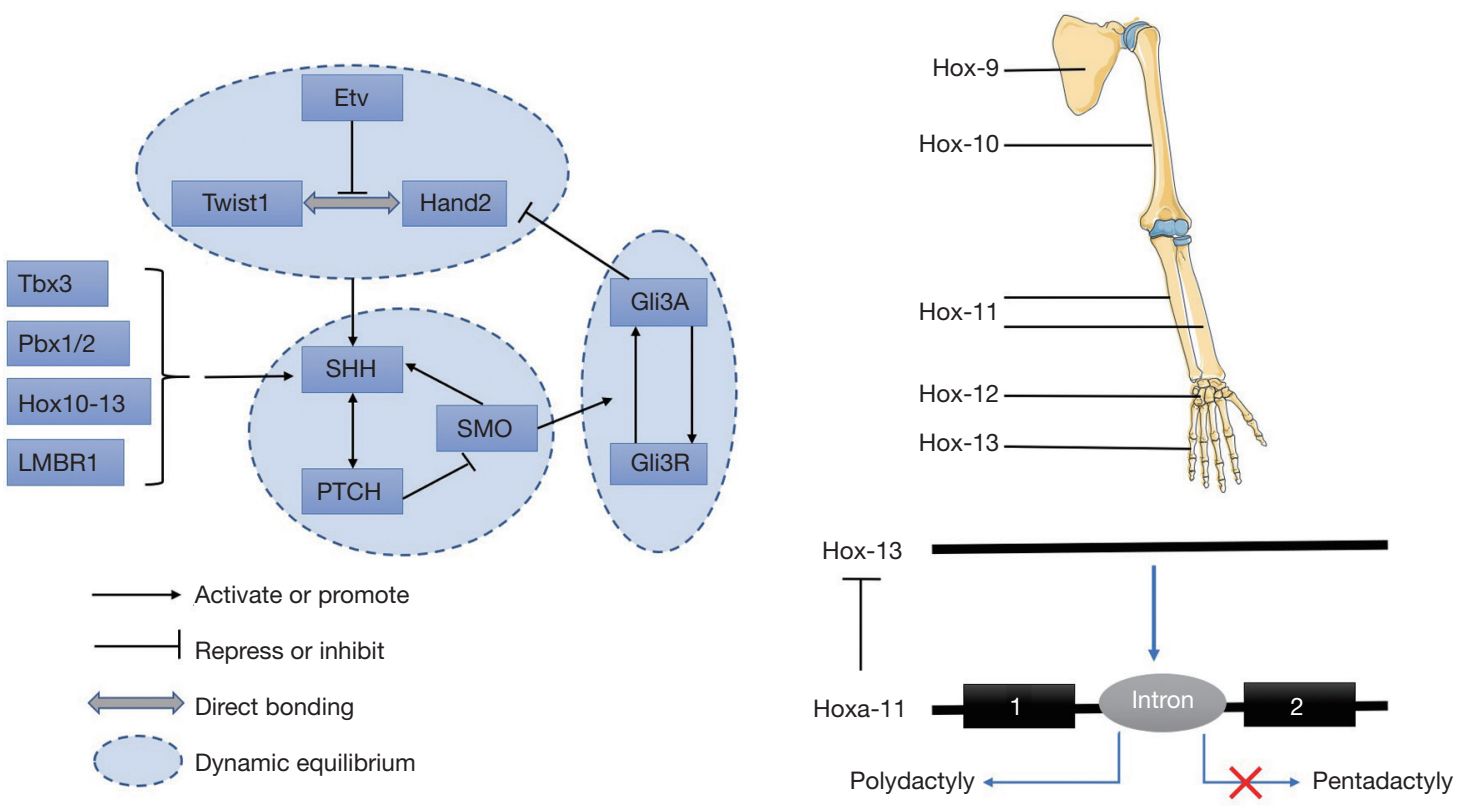

Figure 3 Key signaling pathways and related genes. (A) The specific regulation mechanism of SHH-Gli3 signaling pathway; (B) the hypothesis that Hox gene specializes in specific parts of a limb; (C) the correlation between Hoxa11 and Hox13 in the regulating digits.

also have mutual influence among themselves, so they further constitute a fine regulation network (Figure $3 A$ ). For example, mice with one or two Gli3 alleles destroyed in $S H H$-deficient embryos can gradually restore distal limb development and finger formation. This suggests that $\mathrm{SHH}$ neutralizes Gli3-mediated inhibition of key regulatory genes, cell survival, and distal progression of limb bud development (94).

\section{Hox gene family}

Transcription factors encoded by the Hox gene play a key role in establishing the normal structure of the human body (95). During embryonic development, the genes from each Hox cluster are activated in sequence in time and space according to the relative order on the chromosomes, leading to the differential expression of Hox genes along the main axis of the body, thus establishing morphological diversity (Figure 3B). The limb bone pattern requires the activity of the Hox gene, mainly from the HoxA and $H o x D$ clusters (96-98). During limb development, Hox gene expression is divided into two stages. In the early limb buds, they were expressed in nested patterns along the A-P axis, and the expression of late activated genes was limited to the posterior buds. With the development of the limb, Hox expression entered the second stage, and $H o x A / D$ gene from the heterozygote group was differentially expressed along the P-D axis, and gradually transferred from the proximal to the distal (99). The function loss experiment proved that the differential expression of $H o x A / D$ gene on the P-D axis was the reason for the segment-pattern formation of the three limbs. For example, the combined loss of function of Hoxa11 and Hoxd11 seriously impaired the development of zeugopod, while the inactivation of Hoxa13 and Hoxd13 resulted in complete finger loss $(100,101)$. Hoxa11 and Hoxa13 expression domains are mutually exclusive. The absence of Hoxa11 distally is due to the presence of a transcriptional enhancer within Hoxa11 intron, which upon Hox13-dependent activation, drives antisense transcription that prevents Hoxa11 expression in the presumptive digitforming region. the evolution of Hoxa11 regulation leading to Hoxa11 repression in the Hoxa13 domain must have been implemented prior the emergence of pentadactyly species and has possibly contributed to the transition from polydactyly in stem group tetrapods to pentadactyly in extant tetrapods (102-104) (Figure 3C). For a long time, most researchers believed that the remodeling of distal limbs, from fingerlike limbs to multi-fingered limbs and finally to five-fingered limbs, may depend on the change of Hox regulation during the evolutionary process, while Hox $\mathrm{A}$ and $H o x D$ clusters occurred independently.

Abnormal expression of Hox gene family can lead to 
polydactyly, and dysregulation of $\mathrm{SHH}$ signal can also lead to limb development disorders. So, is this mechanism related to each other? Research shows that ectopic $\mathrm{SHH}$ expression was systematically associated with the PPD in limbs overexpressing $5^{\prime} H o x A / D$ genes, consistent with the function of $5^{\prime} H o x A / D$ genes in controlling $S H H$ expression (105-107). Further, there is evidence that the distally expressed Hox proteins directly interact with Gli3. The study found that the Hoxd12 protein can bind to Gli3, transforming Gli3R into Gli3A. Therefore, once Hoxd12 is overexpressed, the whole SHH-Gli3 signaling pathway will be out of whack, resulting in Polydactyly. The same experimental results were also presented in Hoxd11 and Hoxd13, it was proposed that the ratio between Gli3 and distal Hox family puts on the digit-forming capacity of the distal limb and digit number (108). Sheth et al. combined genetics, quantitative analysis and computer modeling, suggest that the equilibrium resulting from the crossregulation between SHH-Gli3 and distal Hox genes have led to the stabilization of the pentadactyl state (109).

\section{Challenges and perspective}

In recent years, with the rapid development of genetics, molecular biology and embryology, we have a more detailed understanding of the types, phenotypes and genetic patterns of polydactyly. However, the emergence and innovation of technologies such as RNA sequencing, systems bioinformatics, WGS/WES and CRISPR Cas9 can more accurately help us to study the relationship between phenotypes and genotypes. In the foreseeable future, these technologies will provide us with rapid, effective and economical genetic screening, which will help to fully understand the pathogenesis of polydactyly and provide effective intervention against the molecular targets that cause it.

According to the current research, the genes and signaling pathways that cause polydactyly are not single or completely independent, and they often interact with each other or even have a regulatory effect. This suggests that we should systematically consider the relationship between genes, pathways and disease in our research. In addition, we also found that the introduction of Turing machine into the research thought opened a new world for the original understanding of the mechanism of Hox gene family regulating polydactyly $(110,111)$. This also suggests that we should try to conduct interdisciplinary thinking, hypothesis and even experimental design in future research, instead of being trapped in the old research methods and stereotypes.

\section{Acknowledgments}

Funding: This work was supported by the National Key Research and Development Program of China (2016YFC1306900), National Natural Science Foundation of China (81573508, 81874327), and the Strategy-Oriented Special Project of Central South University in China (ZLXD2017003).

\section{Footnote}

Conflicts of Interest: All authors have completed the ICMJE uniform disclosure form (available at http:// dx.doi.org/10.21037/prpm-20-2). HHZ and ZQL serve as the editors-in-chief of Pharmacogenomics Research and Personalized Medicine. The authors have no other conflict of interest to declare.

Ethical Statement: The authors are accountable for all aspects of the work in ensuring that questions related to the accuracy or integrity of any part of the work are appropriately investigated and resolved.

Open Access Statement: This is an Open Access article distributed in accordance with the Creative Commons Attribution-NonCommercial-NoDerivs 4.0 International License (CC BY-NC-ND 4.0), which permits the noncommercial replication and distribution of the article with the strict proviso that no changes or edits are made and the original work is properly cited (including links to both the formal publication through the relevant DOI and the license). See: https://creativecommons.org/licenses/by-nc-nd/4.0/.

\section{References}

1. Malik S. Polydactyly: phenotypes, genetics and classification. Clin Genet 2014;85:203-12.

2. Blauth $W$, Olason AT. Classification of polydactyly of the hands and feet. Arch Orthop Trauma Surg 1988;107:334-44.

3. Castilla E, Paz J, Mutchinick O, et al. Polydactyly: a genetic study in South America. Am J Hum Genet 1973;25:405-12.

4. Malik S, Ullah S, Afzal M, et al. Clinical and descriptive genetic study of polydactyly: a Pakistani experience of 313 cases. Clin Genet 2014;85:482-6. 
5. Wassel HD. The results of surgery for polydactyly of the thumb. A review. Clin Orthop Relat Res 1969;64:175-93.

6. Bílá V, Kren V. Evidence for teratogenicity of thalidomide using congenic and recombinant inbred rat strains. Folia Biol (Praha) 1994;40:161-71.

7. Jentink J, Loane MA, Dolk H, et al. Valproic acid monotherapy in pregnancy and major congenital malformations. N Engl J Med 2010;362:2185-93.

8. Fish EW, Parnell SE, Sulik KK, et al. Preaxial polydactyly following early gestational exposure to the smoothened agonist, SAG, in C57BL/6J mice. Birth Defects Res 2017;109:49-54.

9. Saito K, Suzuki H, Suzuki K. Teratogenic effects of static magnetic field on mouse fetuses. Reprod Toxicol 2006;22:118-24.

10. Yang MJ, Liu JY, Wang YF, et al. Effects of electromagnetic pulse on polydactyly of mouse fetuses. Theriogenology 2013;80:18-23.

11. Zuniga A, Zeller R, Probst $S$. The molecular basis of human congenital limb malformations. Wiley Interdiscip Rev Dev Biol 2012;1:803-22.

12. Biesecker LG. Polydactyly: how many disorders and how many genes? 2010 update. Dev Dyn 2011;240:931-42.

13. Mirzaa G, Parry DA, Fry AE, et al. De novo CCND2 mutations leading to stabilization of cyclin D2 cause megalencephaly-polymicrogyria-polydactylyhydrocephalus syndrome. Nat Genet 2014;46:510-5.

14. Reijnders MR, Zachariadis V, Latour B, et al. De novo loss-of-function mutations in USP9X cause a femalespecific recognizable syndrome with developmental delay and congenital malformations. Am J Hum Genet 2016;98:373-81.

15. Wu PF, Guo S, Fan XF, et al. A novel ZRS mutation in a chinese patient with preaxial polydactyly and triphalangeal thumb. Cytogenet Genome Res 2016;149:171-5.

16. Trimouille A, Tingaud-Sequeira A, Pennamen $P$, et al. Deletion in 2q35 excluding the IHH gene leads to fetal severe limb anomalies and suggests a disruption of chromatin architecture. Eur J Hum Genet 2019;27:384-8.

17. Mullegama SV, Klein SD, Signer RH, et al. Mutations in STAG2 cause an X-linked cohesinopathy associated with undergrowth, developmental delay, and dysmorphia: Expanding the phenotype in males. Mol Genet Genomic Med 2019;7:e00501.

18. Temtamy SA, McKusick VA. The genetics of hand malformations. Birth Defects Orig Artic Ser 1978;14:i-xviii, 1-619.

19. Winter RM, Tickle C. Syndactylies and polydactylies: embryological overview and suggested classification. Eur J Hum Genet 1993;1:96-104.

20. Deng H, Tan T, Yuan L. Advances in the molecular genetics of non-syndromic polydactyly. Expert Rev Mol Med 2015;17:e18.

21. Lettice LA, Horikoshi T, Heaney SJ, et al. Disruption of a long-range cis-acting regulator for Shh causes preaxial polydactyly. Proc Natl Acad Sci U S A 2002;99:7548-53.

22. Burger EB, Baas M, Hovius SER, et al. Preaxial polydactyly of the foot. Acta Orthop 2018;89:113-8.

23. Wieczorek D, Pawlik B, Li Y, et al. A specific mutation in the distant sonic hedgehog ( $\mathrm{SHH}$ ) cis-regulator (ZRS) causes Werner mesomelic syndrome (WMS) while complete ZRS duplications underlie Haas type polysyndactyly and preaxial polydactyly (PPD) with or without triphalangeal thumb. Hum Mutat 2010;31:81-9.

24. Perez-Lopez LM, la Iglesia DG, Cabrera-Gonzalez M. Radial polydactyly. What's new? Curr Pediatr Rev 2018;14:91-6.

25. Potuijt JWP, Baas M, Sukenik-Halevy R, et al. A point mutation in the pre-ZRS disrupts sonic hedgehog expression in the limb bud and results in triphalangeal thumb-polysyndactyly syndrome. Genet Med 2018;20:1405-13.

26. Tsukurov O, Boehmer A, Flynn J, et al. A complex bilateral polysyndactyly disease locus maps to chromosome $7 \mathrm{q} 36$. Nat Genet 1994;6:282-6.

27. Lettice LA, Heaney SJ, Purdie LA, et al. A long-range Shh enhancer regulates expression in the developing limb and fin and is associated with preaxial polydactyly. Hum Mol Genet 2003;12:1725-35.

28. Comer GC, Potter M, Ladd AL. Polydactyly of the hand. J Am Acad Orthop Surg 2018;26:75-82.

29. Wood VE. Duplication of the index finger. J Bone Joint Surg Am 1970;52:569-73.

30. Stenson PD, Mort M, Ball EV, et al. The Human Gene Mutation Database: towards a comprehensive repository of inherited mutation data for medical research, genetic diagnosis and next-generation sequencing studies. Hum Genet 2017;136:665-77.

31. Radhakrishna U, Bornholdt D, Scott HS, et al. The phenotypic spectrum of GLI3 morphopathies includes autosomal dominant preaxial polydactyly type-IV and postaxial polydactyly type-A/B; No phenotype prediction from the position of GLI3 mutations. Am J Hum Genet 1999;65:645-55.

32. Furniss D, Critchley P, Giele H, et al. Nonsense-mediated decay and the molecular pathogenesis of mutations in 
SALL1 and GLI3. Am J Med Genet A 2007;143A:3150-60.

33. Al-Qattan MM. A novel frameshift mutation of the GLI3 gene in a family with broad thumbs with/without big toes, postaxial polydactyly and variable syndactyly of the hands/ feet. Clin Genet 2012;82:502-4.

34. van der Zwaag PA, Dijkhuizen T, Gerssen-Schoorl KB, et al. An interstitial duplication of chromosome $13 \mathrm{q} 31.3 \mathrm{q} 32.1$ further delineates the critical region for postaxial polydactyly type A2. Eur J Med Genet 2010;53:45-9.

35. Lange A, Muller GB. Polydactyly in development, inheritance, and evolution. Q Rev Biol 2017;92:1-38.

36. Zhao H, Tian Y, Breedveld G, et al. Postaxial polydactyly type A/B (PAP-A/B) is linked to chromosome 19p13.1-13.2 in a Chinese kindred. Eur J Hum Genet 2002;10:162-6.

37. Galjaard RJ, Smits AP, Tuerlings JH, et al. A new locus for postaxial polydactyly type A/B on chromosome 7q21-q34. Eur J Hum Genet 2003;11:409-15.

38. Umm-e-Kalsoom, Basit S, Kamran-ul-Hassan Naqvi S, et al. Genetic mapping of an autosomal recessive postaxial polydactyly type A to chromosome 13q13.3-q21.2 and screening of the candidate genes. Hum Genet 2012;131:415-22.

39. Kalsoom UE, Klopocki E, Wasif N, et al. Whole exome sequencing identified a novel zinc-finger gene ZNF141 associated with autosomal recessive postaxial polydactyly type A. J Med Genet 2013;50:47-53.

40. Umair M, Shah K, Alhaddad B, et al. Exome sequencing revealed a splice site variant in the IQCE gene underlying post-axial polydactyly type A restricted to lower limb. Eur J Hum Genet 2017;25:960-5.

41. Pusapati GV, Hughes CE, Dorn KV, et al. EFCAB7 and IQCE regulate hedgehog signaling by tethering the EVCEVC2 complex to the base of primary cilia. Dev Cell 2014;28:483-96.

42. Palencia-Campos A, Ullah A, Nevado J, et al. GLI1 inactivation is associated with developmental phenotypes overlapping with Ellis-van Creveld syndrome. Hum Mol Genet 2017;26:4556-71.

43. Vortkamp A, Gessler M, Grzeschik KH. GLI3 zinc-finger gene interrupted by translocations in Greig syndrome families. Nature 1991;352:539-40.

44. Holmes LB, Nasri H, Hunt AT, et al. Polydactyly, postaxial, type B. Birth Defects Res 2018;110:134-41.

45. Martin RA, Jones MC, Jones KL. Mirror hands and feet with a distinct nasal defect, an autosomal dominant condition. Am J Med Genet 1993;46:129-31.

46. Kondoh S, Sugawara H, Harada N, et al. A novel gene is disrupted at a $14 \mathrm{q} 13$ breakpoint of $\mathrm{t}(2 ; 14)$ in a patient with mirror-image polydactyly of hands and feet. J Hum Genet 2002;47:136-9.

47. Klopocki E, Kahler C, Foulds N, et al. Deletions in PITX1 cause a spectrum of lower-limb malformations including mirror-image polydactyly. Eur J Hum Genet 2012;20:705-8.

48. Farrugia MC, Calleja-Agius J. Polydactyly: a review. Neonatal Netw 2016;35:135-42.

49. Graham TJ, Ress AM. Finger polydactyly. Hand Clin 1998;14:49-64.

50. Hussain M, Glass GE, Moss ALH. An actively mobile accessory digit arising from the dorsum of the foot: an unusual example of polydactyly. Eur J Plast Surg 2007;29:381-3.

51. Nair S, Varghese S, Kumar A, et al. A rare case of central polydactyly. Eur J Plast Surg 2001;24:264-5.

52. Haas SL. Bilateral complete syndactylism of all fingers. Am J Surg 1940;50:363-6.

53. Searls RL, Janners MY. The initiation of limb bud outgrowth in the embryonic chick. Dev Biol 1971;24:198-213.

54. Hall BK, Miyake T. The membranous skeleton: the role of cell condensations in vertebrate skeletogenesis. Anat Embryol (Berl) 1992;186:107-24.

55. Johnson RL, Tabin CJ. Molecular models for vertebrate limb development. Cell 1997;90:979-90.

56. Stephens TD, McNulty TR. Evidence for a metameric pattern in the development of the chick humerus. J Embryol Exp Morphol 1981;61:191-205.

57. Zguricas J, Bakker WF, Heus H, et al. Genetics of limb development and congenital hand malformations. Plast Reconstr Surg 1998;101:1126-35.

58. Capdevila J, Izpisua Belmonte JC. Patterning mechanisms controlling vertebrate limb development. Annu Rev Cell Dev Biol 2001;17:87-132.

59. Ohuchi H, Nakagawa T, Yamamoto A, et al. The mesenchymal factor, FGF10, initiates and maintains the outgrowth of the chick limb bud through interaction with FGF8, an apical ectodermal factor. Development 1997;124:2235-44.

60. Summerbell D. A quantitative analysis of the effect of excision of the AER from the chick limb-bud. J Embryol Exp Morphol 1974;32:651-60.

61. Rowe DA, Fallon JF. The proximodistal determination of skeletal parts in the developing chick leg. J Embryol Exp Morphol 1982;68:1-7.

62. Michaud JL, Lapointe F, Douarin NML. The dorsoventral polarity of the presumptive limb is determined by signals 
produced by the somites and by the lateral somatopleure. Development 1997;124:1453-63.

63. Heikinheimo M, Lawshé A, Shackleford GM, et al. Fgf8 expression in the post-gastrulation mouse suggests roles in the development of the face, limbs and central nervous system. Mech Dev 1994;48:129-38.

64. Savage MP, Hart CE, Riley BB, et al. Distribution of FGF2 suggests it has a role in chick limb bud growth. Dev Dyn 1993;198:159-70.

65. Dono R, Zeller R. Cell-type-specific nuclear translocation of fibroblast growth factor-2 isoforms during chicken kidney and limb morphogenesis. Dev Biol 1994;163:316-30.

66. Crossley PH, Minowada G, Macarthur CA, et al. Roles for FGF8 in the induction, initiation, and maintenance of chick limb development. Cell 1996;84:127-36.

67. Vogel A, Rodriguez C, Izpisúa-Belmonte JC. Involvement of FGF-8 in initiation, outgrowth and patterning of the vertebrate limb. Development 1996;122:1737-50.

68. Riddle RD, Johnson RL, Laufer E, et al. Sonic hedgehog mediates the polarizing activity of the ZPA. Cell 1993;75:1401-16.

69. Zhang Z, Sui P, Dong A, et al. Preaxial polydactyly: interactions among ETV, TWIST1 and HAND2 control anterior-posterior patterning of the limb. Development 2010;137:3417-26.

70. Parr BA, McMahon AP. Dorsalizing signal Wnt-7a required for normal polarity of $\mathrm{D}-\mathrm{V}$ and A-P axes of mouse limb. Nature 1995;374:350-3.

71. Panin VM, Papayannopoulos V, Wilson R, et al. Fringe modulates Notch-ligand interactions. Nature 1997;387:908-12.

72. Dealy CN, Roth A, Ferrari D, et al. Wnt-5a and Wnt$7 \mathrm{a}$ are expressed in the developing chick limb bud in a manner suggesting roles in pattern formation along the proximodistal and dorsoventral axes. Mech Dev 1993;43:175-86.

73. Laufer E, Nelson CE, Johnson RL, et al. Sonic hedgehog and Fgf-4 act through a signaling cascade and feedback loop to integrate growth and patterning of the developing limb bud. Cell 1994;79:993-1003.

74. Haramis AG, Brown JM, Zeller R. The limb deformity mutation disrupts the SHH/FGF-4 feedback loop and regulation of 5' HoxD genes during limb pattern formation. Development 1995;121:4237-45.

75. Verma PK, El-Harouni AA. Review of literature: genes related to postaxial polydactyly. Front Pediatr 2015;3:8.

76. Maas SA, Fallon JF. Single base pair change in the longrange Sonic hedgehog limb-specific enhancer is a genetic basis for preaxial polydactyly. Dev Dyn 2005;232:345-8.

77. Lettice LA, Hill AE, Devenney PS, et al. Point mutations in a distant sonic hedgehog cis-regulator generate a variable regulatory output responsible for preaxial polydactyly. Hum Mol Genet 2008;17:978-85.

78. Li H, Wang CY, Wang JX, et al. Mutation analysis of a large Chinese pedigree with congenital preaxial polydactyly. Eur J Hum Genet 2009;17:604-10.

79. Sagai T, Masuya H, Tamura M, et al. Phylogenetic conservation of a limb-specific, cis-acting regulator of Sonic hedgehog (Shh). Mamm Genome 2004;15:23-34.

80. Masuya H, Sezutsu H, Sakuraba Y, et al. A series of ENU-induced single-base substitutions in a long-range cis-element altering Sonic hedgehog expression in the developing mouse limb bud. Genomics 2007;89:207-14.

81. Park K, Kang J, Subedi KP, et al. Canine polydactyl mutations with heterogeneous origin in the conserved intronic sequence of LMBR1. Genetics 2008;179:2163-72.

82. Maas SA, Suzuki T, Fallon JF. Identification of spontaneous mutations within the long-range limb-specific Sonic hedgehog enhancer (ZRS) that alter Sonic hedgehog expression in the chicken limb mutants oligozeugodactyly and silkie breed. Dev Dyn 2011;240:1212-22.

83. Biesecker LG. What you can learn from one gene: GLI3.J Med Genet 2006;43:465-9.

84. Umair M, Ahmad F, Bilal M, et al. Clinical genetics of polydactyly: an updated review. Front Genet 2018;9:447.

85. Clark RM, Marker PC, Kingsley DM. A novel candidate gene for mouse and human preaxial polydactyly with altered expression in limbs of Hemimelic extra-toes mutant mice. Genomics 2000;67:19-27.

86. Dundar M, Gordon TM, Ozyazgan I, et al. A novel acropectoral syndrome maps to chromosome 7q36. J Med Genet 2001;38:304-9.

87. Cho TJ, Baek GH, Lee HR, et al. Tibial hemimeliapolydactyly-five-fingered hand syndrome associated with a $404 \mathrm{G}>\mathrm{A}$ mutation in a distant sonic hedgehog cis-regulator (ZRS): a case report. J Pediatr Orthop B 2013;22:219-21.

88. Norbnop P, Srichomthong C, Suphapeetiporn K, et al. ZRS 406A>G mutation in patients with tibial hypoplasia, polydactyly and triphalangeal first fingers. J Hum Genet 2014;59:467-70.

89. Vanlerberghe C, Faivre L, Petit F, et al. Intrafamilial variability of ZRS-associated syndrome: characterization of a mosaic ZRS mutation by pyrosequencing. Clin Genet 2015;88:479-483.

90. Albuisson J, Isidor B, Giraud M, et al. Identification 
of two novel mutations in Shh long-range regulator associated with familial pre-axial polydactyly. Clin Genet 2011;79:371-7.

91. Taipale J, Cooper MK, Maiti T, et al. Patched acts catalytically to suppress the activity of Smoothened. Nature 2002;418:892-7.

92. Zhang XM, Ramalho-Santos M, McMahon AP. Smoothened mutants reveal redundant roles for Shh and Ihh signaling including regulation of $\mathrm{L} / \mathrm{R}$ asymmetry by the mouse node. Cell 2001;105:781-92.

93. Galli A, Robay D, Osterwalder M, et al. Distinct roles of Hand 2 in initiating polarity and posterior Shh expression during the onset of mouse limb bud development. PLoS Genet 2010;6:e1000901.

94. te Welscher P, Zuniga A, Kuijper S, et al. Progression of vertebrate limb development through $\mathrm{SHH}$-mediated counteraction of GLI3. Science 2002;298:827-30.

95. Deschamps J, van Nes J. Developmental regulation of the Hox genes during axial morphogenesis in the mouse. Development 2005;132:2931-42.

96. Xu B, Wellik DM. Axial Hox9 activity establishes the posterior field in the developing forelimb. Proc Natl Acad Sci U S A 2011;108:4888-91.

97. Zákány J, Duboule D. Hox genes in digit development and evolution. Cell Tissue Res 1999;296:19-25.

98. Zakany J, Duboule D. The role of Hox genes during vertebrate limb development. Curr Opin Genet Dev 2007;17:359-66.

99. Zákány J, Fromental-Ramain C, Warot X, et al. Regulation of number and size of digits by posterior Hox genes: a dose-dependent mechanism with potential evolutionary implications. Proc Natl Acad Sci U S A 1997;94:13695-700.

100.Davis AP, Witte DP, Hsieh-Li HM, et al. Absence of radius and ulna in mice lacking hoxa-11 and hoxd-11. Nature 1995;375:791-5.

doi: $10.21037 /$ prpm-20-2

Cite this article as: Xie P, Yuan FQ, Zhou HH, Li X, Liu ZQ. The molecular genetics related to polydactyly: an updated review. Pharmacogenomics Res Pers Med 2020.
101. Fromental-Ramain C, Warot X, Messadecq N, et al. Hoxa-13 and Hoxd-13 play a crucial role in the patterning of the limb autopod. Development 1996;122:2997-3011.

102. Kherdjemil Y, Lalonde RL, Sheth R, et al. Evolution of Hoxa11 regulation in vertebrates is linked to the pentadactyl state. Nature 2016;539:89-92.

103. Nakamura T, Gehrke AR, Lemberg J, et al. Digits and fin rays share common developmental histories. Nature 2016;537:225-8.

104. Sheth R, Bastida MF, Kmita M, et al. "Self-regulation," a new facet of Hox genes' function. Dev Dyn 2014;243:182-91.

105. Williams ME, Lehoczky JA, Innis JW. A group 13 homeodomain is neither necessary nor sufficient for posterior prevalence in the mouse limb. Dev Biol 2006;297:493-507.

106.Kmita M, Tarchini B, Zàkàny J, et al. Early developmental arrest of mammalian limbs lacking HoxA/HoxD gene function. Nature 2005;435:1113-6.

107. Tarchini B, Duboule D, Kmita M. Regulatory constraints in the evolution of the tetrapod limb anterior-posterior polarity. Nature 2006;443:985-8.

108. Chen Y, Knezevic V, Ervin V, et al. Direct interaction with Hoxd proteins reverses Gli3-repressor function to promote digit formation downstream of Shh. Development 2004;131:2339-47.

109. Sheth R, Marcon L, Bastida MF, et al. Hox genes regulate digit patterning by controlling the wavelength of a Turingtype mechanism. Science 2012;338:1476-80.

110. Economou AD, Green JB. Thick and thin fingers point out Turing waves. Genome Biol 2013;14:101.

111. Kherdjemil Y, Kmita M. Insights on the role of hox genes in the emergence of the pentadactyl ground state. Genesis 2018. doi: 10.1002/dvg.23046. 